\title{
Газетный фонд Национального архива Республики Тыва
}

\author{
Мая С. Маадыр \\ Тувинский государственный университет, Российская Федерация, \\ Марионелла М. Седип-оол \\ Национальный архив Республики Тыва, Российская Федерация
}

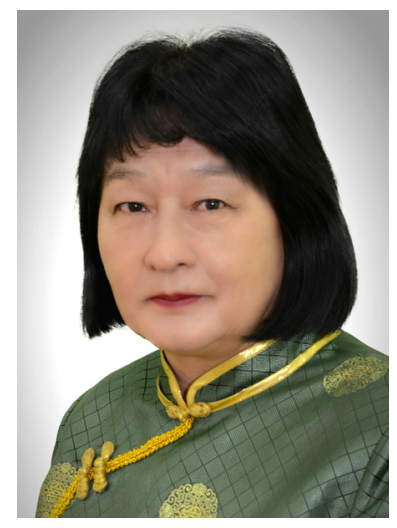

В статье впервые анализируется газетный фонд Национального (до 07.04.2020 2. Государственного) архива Республики Тыва: состав, характеристики, сохранность. Хранящиеся в нем 627 газетных комплектов - с 1914 по 2013 г2. - это местные газеты, а также бурятские, монгольские (выписывались из Бурятии и Монголии). Республиканские газеты разделены на группы: газеты Тувинской Народной Республики, советской Тувы и современной Тувы.

Больше внимания уделено газетам ТНР, это наиболее ценные 43 комплект-подшивок. Это комплекты «Красного пахаря», «Тувинской правды», «Şьп» («Правда»), «Тьва arattbn şьпь» («Правда тувинского арата»), «Хоstyб arat» («Свободный арат») и другие периодические издания, выходившие на территории республики с 1924 по 194422. Представлены также сведения о выпускающих органах, языке издания и наличие в архиве газетных подшивок. Но сами подшивки имеют пробелы. Проанализированы содержания газет периода ТНР. Даны основные темы, приведены примеры, указаны даты.

Фиксируется рост ежегодной выдачи газетных подшивок из архивохранилища для работы в читальном зале архива. Рассматривается статистика запросов и работы читателей.

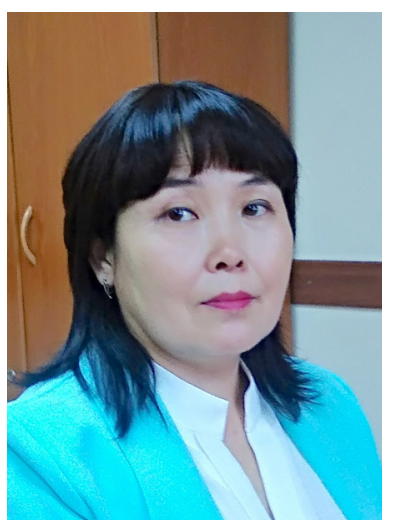

Среди проблем сохранности: случаи ухудшения физического состояния газет, читаемости текстов, появление механических повреждений. Сотрудники формируют комплекты-подшивки и переплетают их, хранят надлежащим образом. Разрабатывается программа по оцифровке газет. Составляется каталог газетного фонда.

Ключевые слова: газетный фонд; Государственный архив Республики Тыва; Национальный архив Республики Тыва; Тува; СМИ; газеты

\section{Для цитирования:}

Маадыр М. С., Седип-оол М. М. Газетный фонд Национального архива Республики Тыва // Новые исследования Тувы. 2020, № 2. C. 87-102. DOI: www.doi.org/10.25178/nit.2020.2.6

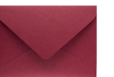

Маадыр Мая Салчаковна - кандидат исторических наук, старший преподаватель кафедры всеобщей истории, археологии и документоведения Тувинского государственного университета. Адрес: 667000, Россия, г. Кызыл, ул. Ленина, д. 5. Тел.: +7 (983) 365-86-25. Эл. адрес: mms-60@mail.ru ORCID ID: 0000-0002-4885-8757

Седип-оол Марионелла Марий-ооловна - начальник отдела государственного учета и обеспечения сохранности архивных документов Национального архива Республики Тыва. Адрес: 667010, Россия, г. Кызыл, ул. Кечил-оола, д. 91. Тел.: +7 (394-22) 5-64-39. Эл. адрес: msedipool@mail.ru ORCID ID: 0000-0002-2532-6571

Maadyr Maja Salchakovna, Candidate of History, Senior Lecturer, Department of General History, Archaeology and Document Studies, Faculty of History, Tuvan State University. Postal address: 5 Lenin St., 667000 Kyzyl, Russian Federation. Tel.: +7 (983) 365-86-25. E-mail:mms-60@mail.ru

Sedip-ool Marionella Marij-oolovna, Head, Department of Management and Preservation of Archival Documents, National Archives of the Republic of Tuva. Postal address: 91 Kechil-ool St., 667003 Kyzyl, Russian Federation. Tel.: +7 (394-22) 5-64-39. E-mail: msedipool@mail.ru 


\title{
Newspaper collections at the National Archives of the Republic of Tuva
}

\author{
Maja S. Maadyr \\ Tuvan State University, Russian Federation, \\ Marionella M. Sedip-ool \\ National Archives of the Republic of Tuva, Russian Federation
}

For the first time, the article analyzes the newspaper collections at the National Archives (prior to 07.04.2020 known as the State Archives) of the Republic of Tuva, its composition, features and degree of preservation. Preserved there are 627 sets of newspapers published between 1929 and 2013. All of these are local newspapers or those delivered by subscription from Buryatia and Mongolia. Tuvan newspapers come in three categories - those published under the Tuvan People's Republic, under the Soviet Union or in contemporary Tuva.

The biggest focus in the article is made, naturally, on the first group. Collected in 48 binders, these sets are of greatest value, and include such newspapers as The Red Plowman, Tuvinskaya Pravda, Şbn (Pravda), TbBa Arattbn Şbnb (Pravda of the Tuvan Arat), Xostyg Arat ("Free Arat") and other periodicals that were published in the republic from 1924 to 1944. They appeared in Russian, Mongolian and Tuvan and were printed in fonts of different alphabets: Old Mongolian, New Turkic Latinized and Russian. The collection also offers catalogized metadata, including their publishing bodies, language(s) and years of publication. However, some of the issues are missing. The article analyzes the content of these newspapers, focusing on preferred topics, dates and typical cases.

There has been a growth in interest in the history of Tuvan newspapers as seen from the number of orders in the archive's reading room. The article also looks at the statistics of readers' use of the collection.

Unresolved issues include worsening of the newspapers' physical condition, lower readability, and mechanical damage to the pages. The archives' employees bind newspapers together in sets to protect them from wear and improve storage conditions. A program to digitize the collection is under development, and the collection itself is being catalogized.

Keywords: newspaper collection; State Archives of the Republic of Tuva; National Archives of the Republic of Tuva; Tuva; mass media; newspapers

\section{For citation:}

Maadyr M. S. and Sedip-ool M. M. Newspaper collections at the National Archives of the Republic of Tuva. The New Research of Tuva, 2020; 2: 87-102. (In Russ.). DOI: www.doi.org/10.25178/nit.2020.2.5

\section{Введение}

Газеты и газетные подшивки для архивистов - это полноценные документы постоянного срока хранения, имеющие историческое, научное и культурное значение. Они являются одним из важных источников, способствующих изучению истории региона, государства, отдельных отраслей и многих других вопросов. Газеты, как издания, оперативно отражающие информацию о событиях и фактах конкретного времени, в настоящее время широко используются исследователями. Часто именно в газетах обнаруживаются ценные и интересные сведения, которые больше нигде не отражены. В настоящее время в фондах государственных архивов Российской Федерации газеты занимают видное место.

Газетный мир Тувы разнообразен и уникален. В Национальном архиве Республики Тыва (Государственном архиве Республики Тыва, ГА РТ) ${ }^{1}$ хранятся 627 комплект-подшивок, в которых собраны газеты, выходившие на ее территории с 1924 г., а также выписывавшиеся из других регионов. Комплектование газетного фонда архива велось разными способами: ежегодной подпиской, получением обязательного

\footnotetext{
${ }^{1}$ В связи с тем, что переименование архива пришлось на период предпечатной подготовки статьи (7 апреля 2020 г.) далее мы сохраняем в тексте старое название "Государственный архив Республики Тыва" и аббревиатуру "ГА РТ". - ред.

Editors' note: Since the Archives was renamed while editorial work on the article was already under way (April 7, 2020), we have preserved at some places the institution's old name - "State Archives of the Republic of Tuva".
} 
местного экземпляра, дарами учреждений и отдельных людей. Газеты Тувинской Народной Республики (ТНР) поступили в свое время от организаций и учреждений.

Отечественная периодическая печать, в том числе газеты, представляют несомненный интерес для исследователей. Значительный вклад в разработку проблемы внес, например, Б. И. Есин, который исследовал задачи и теоретико-методические принципы газетного дела в России (Есин, 1981). К недавним работам относится исследование А. М. Грибановской, посвященное крупным газетам России второй половины XIX в., деятельности их редакций (Грибановская, 2017).

Результаты исследований по данной проблеме регулярно освещаются также в специализированном историко-архивоведческом журнале «Вестник архивиста». Из работ последних лет можно отметить, например, статью Л. П. Ледкова о роли периодической печати в сельскохозяйственном просвещении Забайкалья, написанную по материалам Государственного архива Забайкальского края (Ледкова, 2016); публикацию М. Н. Потемкиной, Н. Н. Макаровой и А. Е. Любецкой о тюремной прессе, в том числе газетах, как источнике по истории большевистской оппозиции конца 1920 - начала 1930-х гг. (Потемкина, Макарова, Любецкий, 2018).

Среди исследований иного типа имеются работы и о сибирских газетах, которые рассмотрены как источники повседневной жизни территории, в частности, С. Г. Сизова об омских периодических изданиях 1918-1919 гг. (Сизов, 2018) или Д. Л. Шереметьевой о газетах в период «демократической контрреволюции» (Шереметьева, 2011). Однако в большей части в этих работах газеты рассмотрены как предмет исторического изучения. Близкой к нашему вопросу является публикация о газетном фонде научной библиотеки Томского государственного университета (Косова, Данилова, 2018). Авторы детально осветили вопросы о сохранности, оцифровке и использовании как местных, так привозных газет.

Газетный фонд Государственного архива Республики Тыва до настоящего времени не был объектом историко-архивоведческого изучения. Имеются две монографии, посвященные в целом истории появления и развития периодической печати в республике - Е. Т. Тановой (Танова, 1979) и В. С. Кан (Кан, 2011). В них получили освещение предпосылки возникновения первых тувинских газет, постепенное увеличение их количества, тематическое содержание газет и ряда журналов, их роль в социально-экономическом развитии Тувы. В ряде статей В. С. Кан также рассмотрены мероприятия по усилению роли периодической печати в тувинском обществе (Кан, 2010b), история становления газеты «Сылдысчыгаш» (Кан, 2010а) и некоторые другие вопросы. Однако в них газеты рассмотрены, как и в указанных выше работах, как предмет исторического изучения.

В последние годы все же предпринимаются попытки анализа отдельных частей состава фондов ГА PT. В этом плане можно назвать статью одного из соавторов данной статьи - о журналах Тувинской Народной Республики (Маадыр, 2018), а также статью Ч. Б. Шактар-оол - о кинодокументах, хранящихся в Государственном архиве и других архивохранилищах Республики Тыва (Шактар-оол, 2018).

Цель представленной статьи - проанализировать газетный фонд Государственного архива Республики Тыва. Более подробному изучению (по названиям и содержанию) подверглись газеты периода THР, т. к. они на сегодня являются наиболее ценными изданиями, восполнить состав которых практически не представляется возможным. Затронуты вопросы состояния сохранности газет, их использования как самими архивистами, так и исследователями.

\section{Состав газетного фонда}

Хранящиеся в ГА РТ газетные комплекты условно распределены на 3 группы: республиканские; бурятские и монгольские; центральные. Первую группу составляют газеты, выходившие и продолжающие выходить в Туве; ко второй группе - выписывавшиеся из Монголии и Бурятии; а к третьей - выходившие в Москве В этих группах 627 комплектов. Наличие второй группы объясняется тем, что в целях обеспечения слушателей курсов монгольского и русского языков, созданных в Кызыле, Центральный комитет Тувинской народно-революционной партии (ЦК ТНРП) отправлял в Улан-Батор и Улан-Удэ своих представителей специально для приобретения журналов, газет и книг (Танова, 1979: 19). В ходе формирования архивного фонда страны в 1940-е гг. они были переданы в ГА ТНР.

Республиканские газеты, хранящиеся в архиве, издавались в Туве с 1929 по 2013 гг. Не сохранились издания первых лет становления национального издательского дела - с 1924 по 1928 гг. Газеты 1914-2013 гг., хранящиеся в архиве, переплетены, а местные издания 2014-2020 гг. собраны по 


\section{НОВЫЕ ИССЛЕДОВАНИЯ ТУВЫ}

www.nit.tuva.asia

\section{THE NEW RESEARCH OF TUVA}

2020

Novye issledovaniia Tuvy

хронологии. Имеющиеся республиканские газеты распределены на три подгруппы: газеты Тувинской Народной Республики, газеты советской Тувы и газеты современной Тувы, т. е. постсоветского периода.

Газеты ТНР собраны в 43 подшивках. Это комплекты «Красного пахаря», «Вперед», «Тувинской правды», «Нового пути», «Şьп» («Шын»), «Тьва arattьn şьnь» ( «Правда тувинского арата»), «Хostyø arat» («Свободный арат»), «Areve şьnь» («Правда ревсомола») и «Revane şьnь» («Ревсомольская правда»).

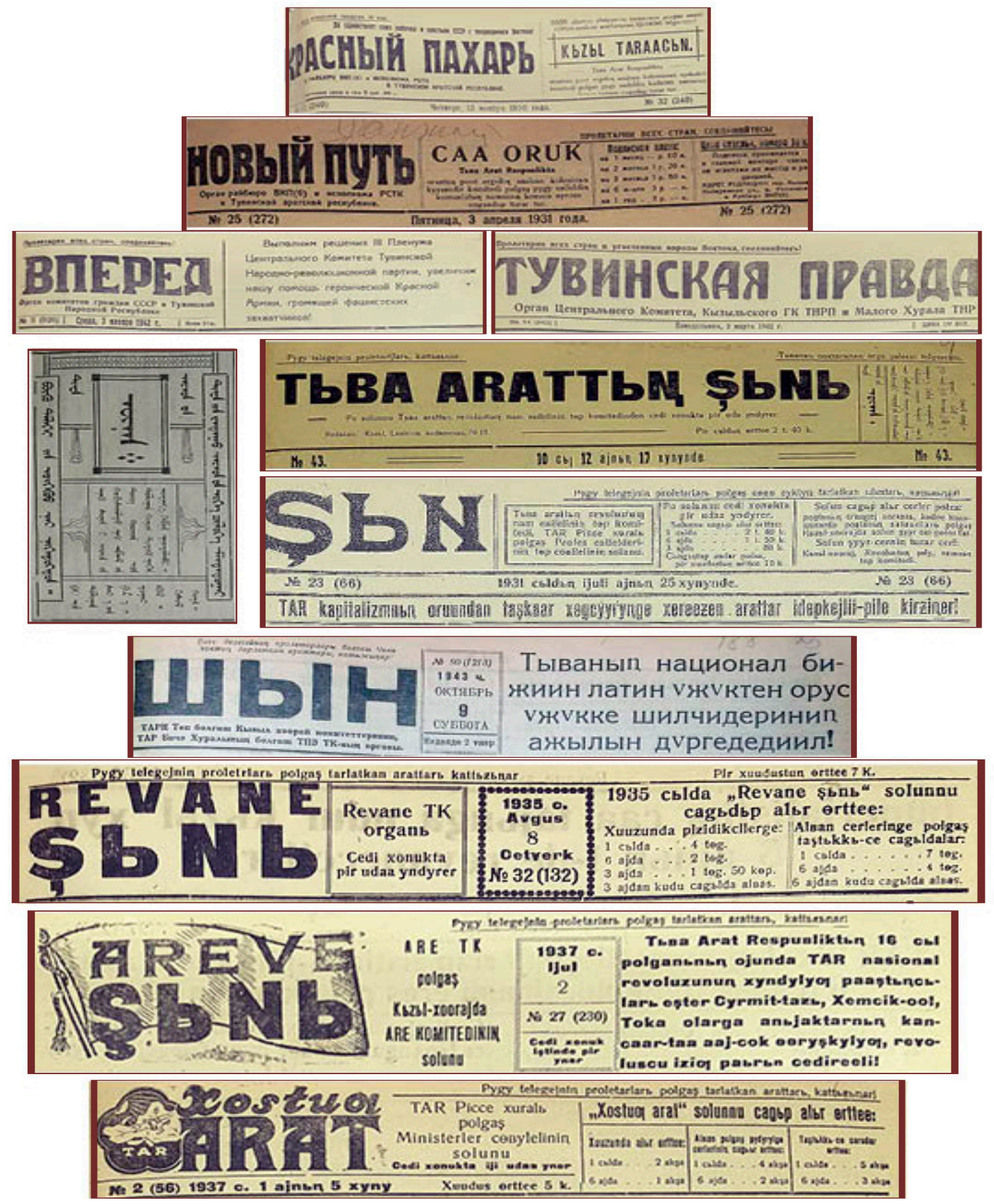

Фото 1. Заголовочные части газет Тувинской Народной Республики,

хранящихся в газетном фонде Государственного архива Республики Тыва.

Photo 1. Newspaper headers from the years of Tuvan People's Republic (Newspaper collection, SA RT). 
Газеты советского и постсоветского периодов в фонде представлены республиканскими и кожунными, т. е. районными. Это: «Шын» («Правда»), «Тувинская правда», «Сталинское племя», «Тываның аныяктары» («Молодежь Тувы» на тувинском языке), «Молодежь Тувы» (на русском языке), «Тыва Республика», «Сылдысчыгаш», а также «Вести Кызыла», «Плюс Информ», «Риск-Информ», «Содействие», «Центр Азии», «Эне сөзү» и «Эфир» с 1946 по 2003 гг. Комплекты кожуунных газет составляют более многочисленную часть. В советский период в Туве выходили более 20 названий. В газетном фонде на тувинском языке имеются «Бурунгаар», «Колхозчу», «Ленинчи орук», «Коммунизмниң түгү», «Коммунистиг күш-ажыл дээш», «Кызыл тук», «Сталинчи», «Хемчиктиң сылдызы», «Улуг-Хем» и «Чаа амыдырал» за 1951-1991 гг. На русском языке хранятся «Большевик», «За коммунистический труд», «Знамя коммунизма», «Колхозник», «Коммунист», «Красное знамя», «Ленинский путь», «Сталинец» и «Сталинское племя» за 1946-1965 гг. В госархиве имеется также газета-многотиражка «За асбест» за 1974-1989 гг., выпускавшаяся Ак-Довуракской асбестовой фабрикой.

Из распространявшихся на территории Тувы бурятских и монгольских газет в архиве содержатся «Нийслэл хүрээний үнэн бичиг» за 1915, 1917-1919 гг., «Монголын сонин бичиг» за 1914-1916, 1918-1919 гг. и «Монголын үнэн» за 1930-1931 гг.

Рассмотрим газеты периода ТНР. Они распределены, как мы отметили выше, в 43 комплект-подшивках. В представленной ниже таблице даны сведения о названиях и выпускающих органов газет, языке их издания и за какие годы хранятся в архиве.

Таблица. Газеты Тувинской Народной Республики, хранящиеся в Государственном архиве Республики Тыва

Table. Newspapers of the People's Republic of Tuva preserved at the State Archives of the Republic of Tuva

\begin{tabular}{|c|c|c|c|}
\hline Название газет, начало выхода & Выпускающий орган & Язык & $\begin{array}{l}\text { Годовые подшивки, } \\
\text { имеющциеся в архиве }\end{array}$ \\
\hline $\begin{array}{l}\text { «Красный пахарь». } \\
\text { Издавалась в 1924-1931 гг. }\end{array}$ & $\begin{array}{l}\text { Районное бюро } \\
\text { РКП(б) и исполком } \\
\text { Русской } \\
\text { самоуправляющейся } \\
\text { трудовой колонии ТНР } \\
\text { (РСТК) }\end{array}$ & Русский & 1929-1930 гг. \\
\hline $\begin{array}{l}\text { «Новый путь» } \\
\text { Издавалась в 1931-1932 гг. } \\
\text { (до этого «Красный } \\
\text { пахарь») }\end{array}$ & $\begin{array}{l}\text { Райбюро РКП(б) и } \\
\text { исполком РСТК }\end{array}$ & Русский & 1931-1932 гг. \\
\hline $\begin{array}{l}\text { «Вперед». } \\
\text { Издавалась в 1932-1942 гг. } \\
\text { (до этого «Новый путь») }\end{array}$ & $\begin{array}{l}\text { Клуб граждан СССР в } \\
\text { ТНР; Комитет советских } \\
\text { граждан в ТНР }\end{array}$ & Русский & $\begin{array}{l}1932-1937 \text { гг., } \\
1940 \text { г., } \\
1942 \text { г. }\end{array}$ \\
\hline $\begin{array}{l}\text { «Тувинская правда». } \\
\text { Издается с } 1942 \text { г. } \\
\text { по настоящее время; } \\
\text { (до этого «Вперед») }\end{array}$ & $\begin{array}{l}\text { Центральный и } \\
\text { Кызыльский комитеты } \\
\text { ТНРП и } \\
\text { Малый Хурал ТНР }\end{array}$ & Русский & 1942-1944 гг. \\
\hline $\begin{array}{l}\text { «Тува ардын үнэн» } \\
\text { («Правда тувинского } \\
\text { арата»). Издавалась в } \\
\text { 1929-1930 гг. }\end{array}$ & ЦК ТНРП & Монгольский & 1930 г. \\
\hline $\begin{array}{l}\text { «Тьва arattın şьnь» } \\
\text { («Правда тувинского арата»). } \\
\text { Издавалась в 1930-1931 гг. }\end{array}$ & ЦК ТНРП & $\begin{array}{l}\text { Монгольский, } \\
\text { тувинский }\end{array}$ & 1931 г. \\
\hline
\end{tabular}




\begin{tabular}{|c|c|c|c|}
\hline $\begin{array}{l}\text { «Şьn» («Правда»). } \\
\text { Издавалась с } 1931 \text { г.; до этого } \\
\text { «Тьва arattьn şьnь» }\end{array}$ & $\begin{array}{l}\text { ЦК ТНРП и ТРСМ, } \\
\text { Малый Хурал и } \\
\text { Центральный Совет } \\
\text { Профсоюза ТНР }\end{array}$ & Тувинский & $\begin{array}{l}\text { 1931-1938 гг., } \\
\text { 1941-1944 гг. }\end{array}$ \\
\hline $\begin{array}{l}\text { «Xostuq arat». } \\
\text { Издавалась в 1936-1942 гг. }\end{array}$ & $\begin{array}{l}\text { Малый Хурал и } \\
\text { Совет Министров } \\
\text { THР }\end{array}$ & Тувинский & 1936-1941 гг. \\
\hline $\begin{array}{l}\text { «Реванэ шыны» } \\
\text { («Ревсомольская правда»). } \\
\text { Издавалась в 1933-1936 гг. }\end{array}$ & $\begin{array}{l}\text { Центральный } \\
\text { Комитет Тувинского } \\
\text { революционного союза } \\
\text { молодежи }\end{array}$ & Тувинский & 1933-1935 гг. \\
\hline $\begin{array}{l}\text { «Аревэ шыны» } \\
\text { («Правда ревсомола») } \\
\text { Издавалась в 1936-1944 гг. }\end{array}$ & $\begin{array}{l}\text { Центральный } \\
\text { Комитет Тувинского } \\
\text { революционного союза } \\
\text { молодежи }\end{array}$ & Тувинский & $\begin{array}{l}1936-1937 \text { гг., } \\
1939 \text { г., } \\
1942-1944 \text { гг. }\end{array}$ \\
\hline
\end{tabular}

Как видно из таблицы, от первой газеты ТНР «Красного пахаря», печатного органа районного бюро РКП(б) и исполкома Русской самоуправляющейся трудовой колонии (РСТК) ТНР, в ГА РТ сохранились номера всего двух лет - 1929 и 1930 г. Отсутствуют номера целых пяти лет: с 1924 по 1928 гг. В последующие годы название газеты несколько раз менялось: с 1931 г. выходила под названием «Новый путь», с 1932 г. - «Вперед», а с 1942 г. по настоящее время - «Тувинская правда». Менялись также выпускающие органы: в 1932 г., в связи с реорганизацией РСТК, газета стала печатным органом Комитетов советских граждан (КСК). До настоящего времени сохранились номера этих газет с 1931 по 1944 гг.

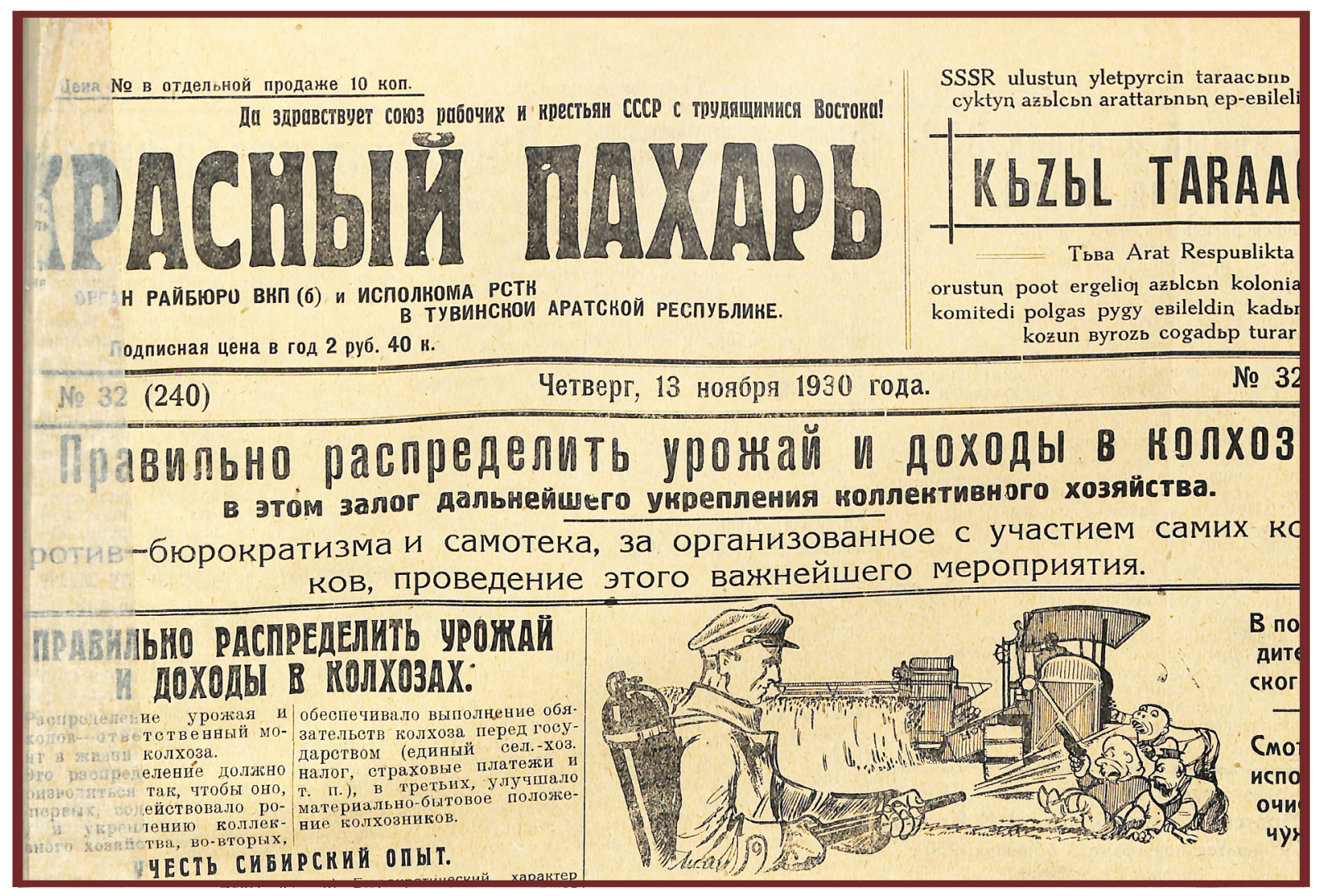

Фото 2. Первая полоса газеты «Красный пахарь» от 13 ноября 1930 г., хранящейся в газетном фонде Государственного архива Республики Тыва.

Photo 2. The front page of the November 13, 1930 issue, Krasny Pakhar' (Red Ploughman) newspaper (Newspaper collection SA RT). 

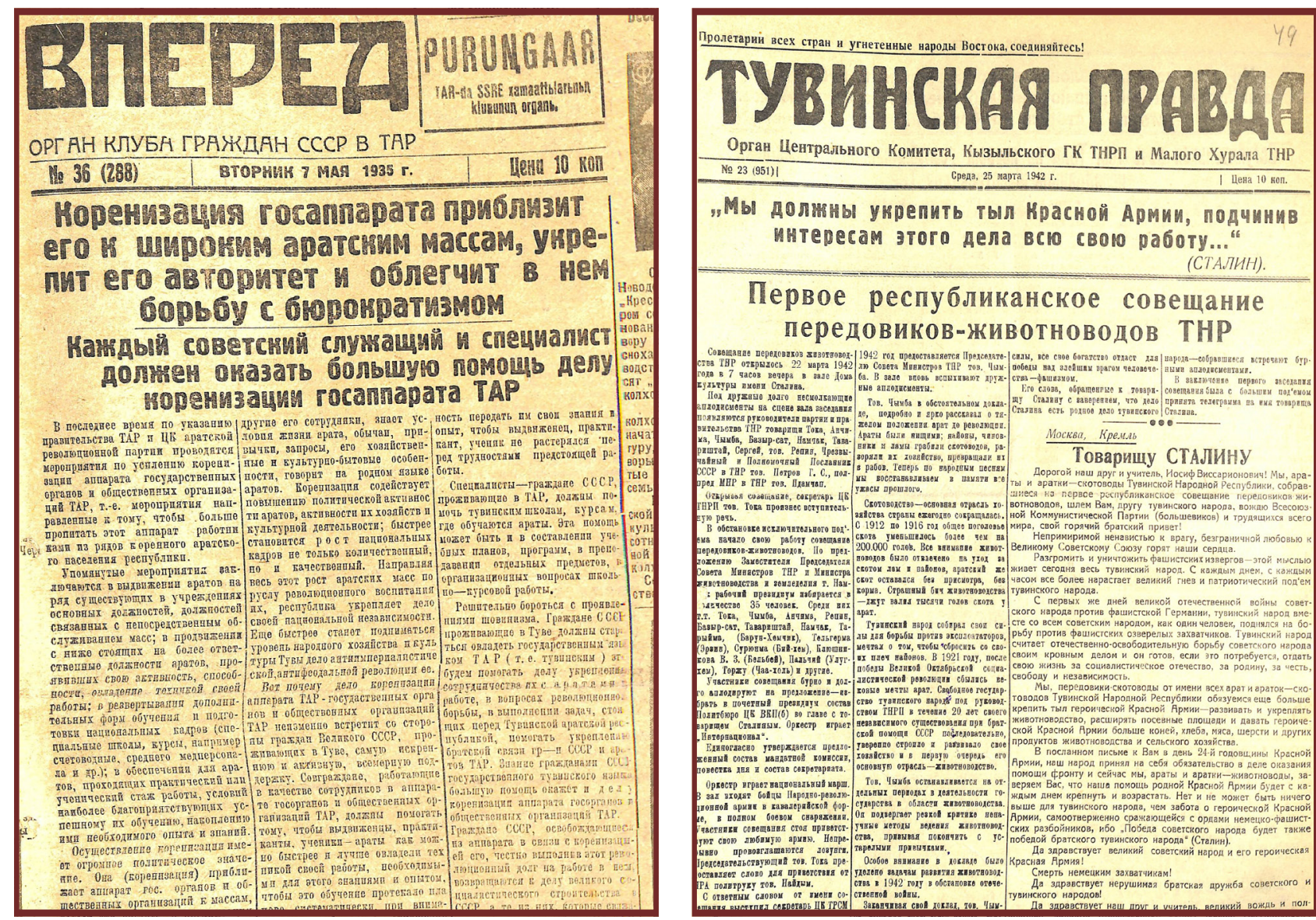

"Мы долины укрепить тыл Красиой Армии, подчинив интересам зтого дела всю свою работу...

Первое республиканское совещание передовиков-животноводов ТНР

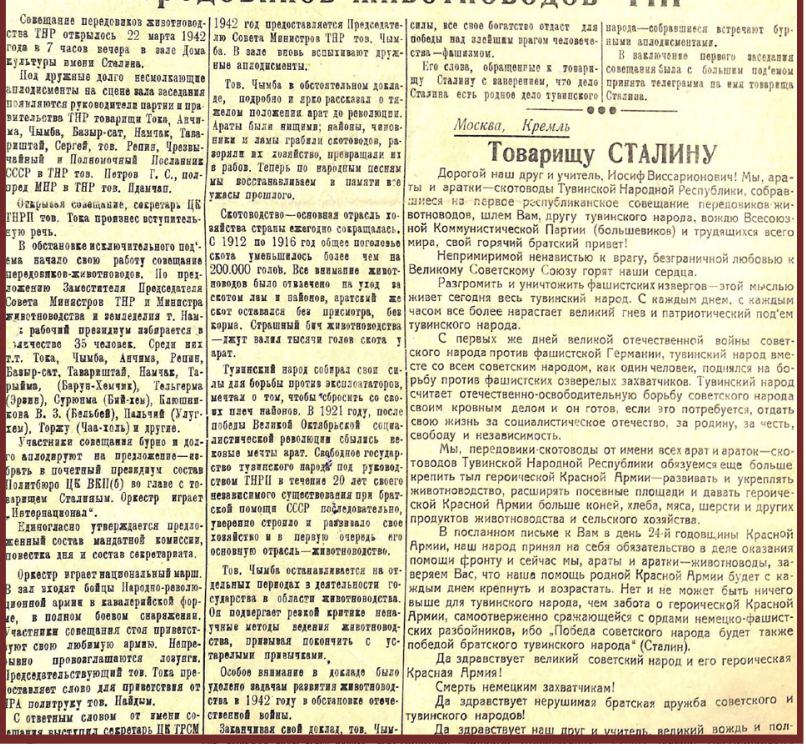

Фото 3-4. Первая полоса газет: «Вперед» от 7 мая 1935 г. и «Тувинская правда» от 25 марта 1942 г., хранящихся в газетном фонде Государственного архива Республики Тыва.

Photo 3-4. The front page of the May 7, 1935 issue, Vperiod (Forward) newspaper and March 25, 1942 issue of the Tuvinskaya Pravda (Newspaper collection SA RT).

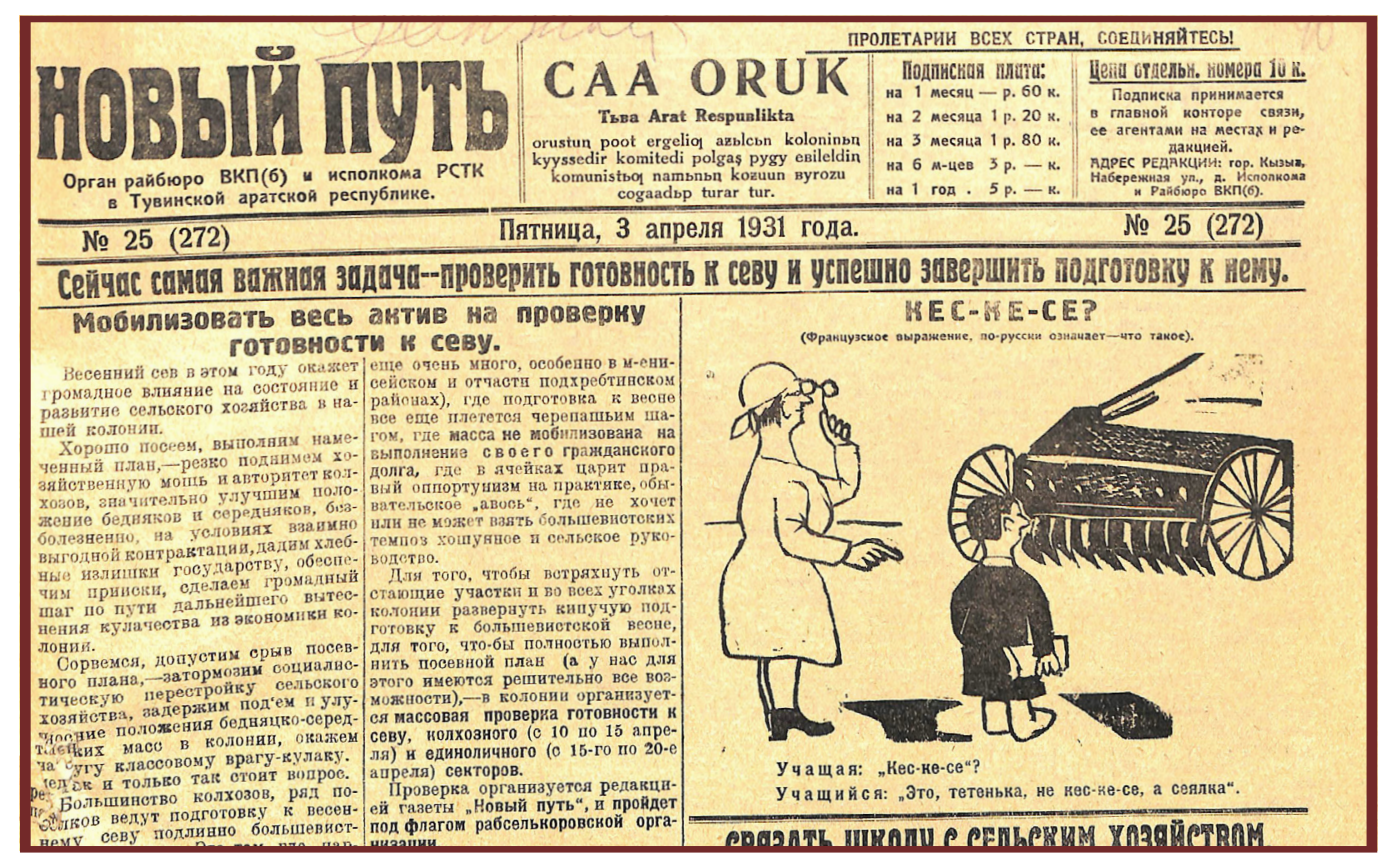

Фото 5. Первая полоса газеты «Новый путь» от 3 апреля 1931 г.,

хранящейся в газетном фонде Государственного архива Республики Тыва.

Photo 5. The front page of the April 3, 1931 issue of the Novy Put' (Newspaper collection SA RT). 
Подшивки «Тувинской правды» являются более полными. Однако они хронологически не систематизированы. Например, комплект-подшивка за 1942 г. начинается с № 68 и «дошел» до № 137, которые выходили с 15 июля по 29 декабря, а затем идут №№ с 48 по 67, выходившие с 29 мая по 12 июля. После этого есть №№ 26-47 (со 2 апреля по 27 мая) и т. д. В общей совокупности в данную подшивку включены 133 номера, выходившие с 28 января по 29 декабря 1942 г. Вовсе отсутствуют 4 номера: №№ 2, 30, 81 и 127.

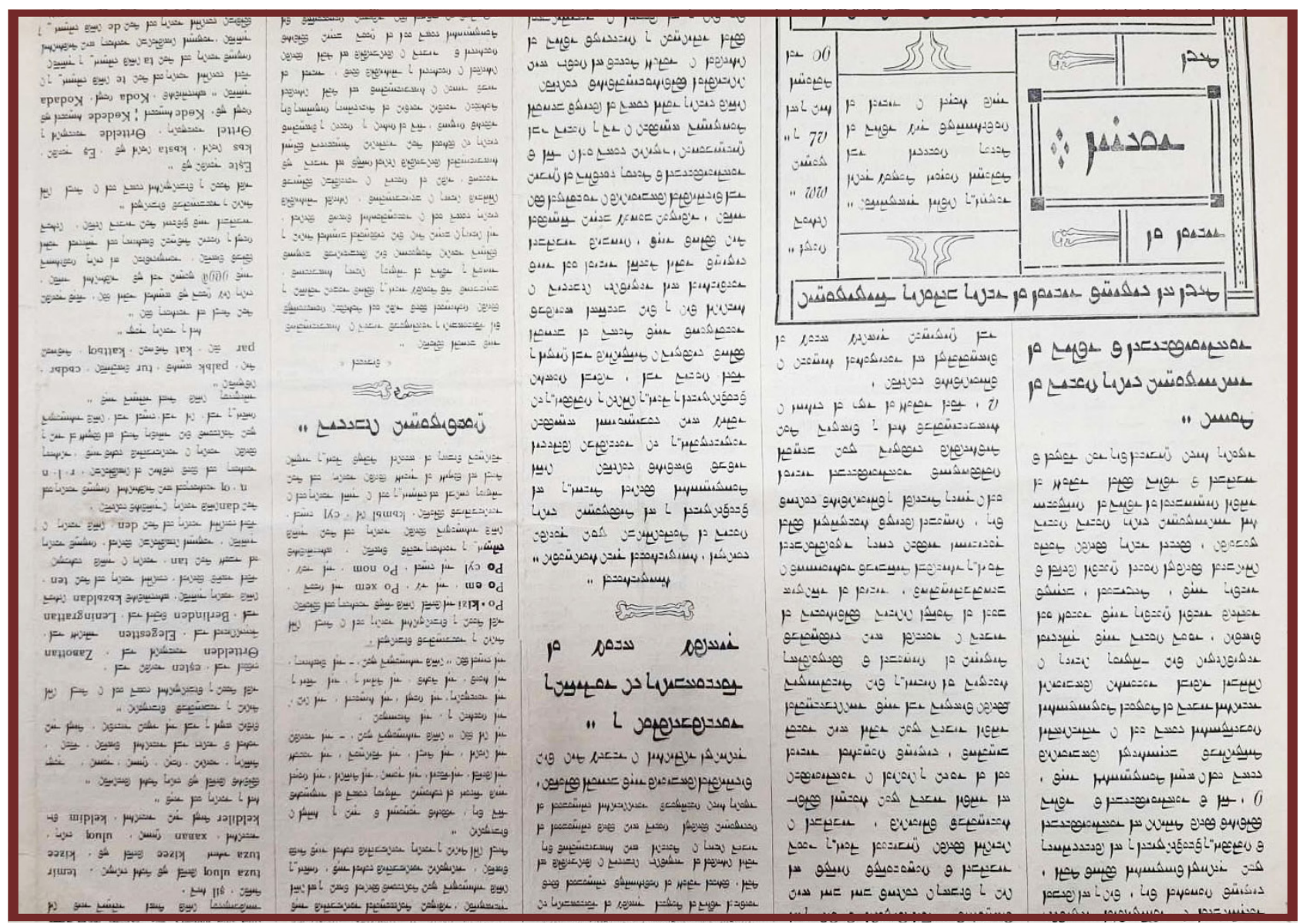

Фото 6. Первая полоса газеты «Тува ардын үнэн», хранящейся в газетном фонде Государственного архива Республики Тыва. Photo 6. The front page of the Tuva Ardyn Ünen newspaper (Newspaper collection SA RT).

Предшественниками нынешней газеты «Шын» («Правда») были «Танну-Тувагийн үнэн» («ТаннуТувинская правда», 1926-1930 гг.), «Тува ардын үнэн» (1930 г.) и «Тьва arattьn şьnь» («Правда тувинского арата», 1930-1931 гг.), которые и выходили на монгольском языке. К моменту введения тувинской письменности в июне 1930 г., разработанной на основе новотюрского латинизированного алфавита «Тува ардын үнэн» была переименована в «Тьва arattьn şьnь», а с 14 августа ее первая полоса стала выходить на тувинском языке.

От данной газеты, печатного органа Центрального комитета Тувинской народно-революционной партии (ЦК ТНРП), в ГА РТ хранятся всего несколько номеров за 1930-1931 гг. В январе 1931 г. газета переименована в «Шын» и стала выходить полностью на тувинском языке.

Более полные годовые комплекты в фонде ГА РТ у молодежной газеты ЦК ТРСМ «Реванэ шыны» («Ревсомольская правда»), которая в 1936 г. была переименована в «Аревэ шыны» («Правда ревсомола»).

Таковыми являются также комплекты «Хостуг арат» («Свободный арат») - газеты Малого Хурала и Совета Министров ТНР.

Как мы уже упомянули, не все годовые комплекты хранятся в полном виде, в подшивках отсутствуют многие номера газет. По всей вероятности, в свое время газетные комплекты-подшивки формировались несколько хаотично, собиратели особо не обращали внимание на названия, на полноту и хронологию номеров. Например, в одной подшивке собраны несколько разных газет за разные годы. 


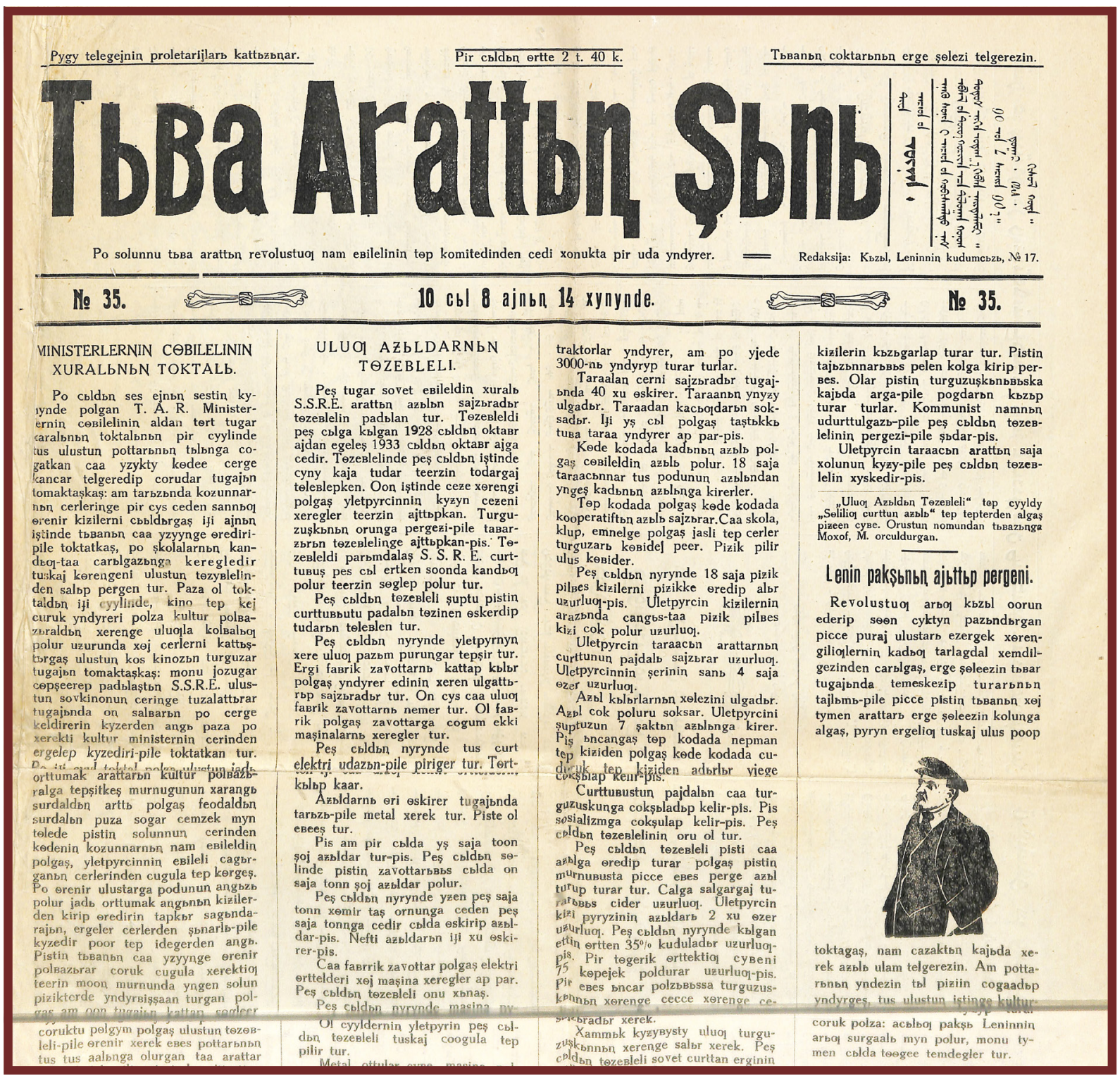

Фото 7. Первая полоса газеты «Тьва аrattbn şьпь», хранящейся в газетном фонде Государственного архива Республики Тыва. Photo 7. The front page of the Tьва aratton şsnь newspaper (Newspaper collection SA RT).

Так, на обложке одной из таких подшивок отмечено: «Тьва arat» 1930, 1921 гг., «Xostuq arat» 1937 г., «"Şьn” 1932 г., 167 листов». Внутреннее содержание подшивок показывает, что под названием «Тыва арат» имелась в виду газета «Тьва arattьn sьnь» («Правда тувинского арата»), а надпись «1921 г.» - это ошибка технического характера, имелся в виду «1931 г.». Данная газета в подшивке представлена всего двумя номерами: № 1 за 1931 г. и № 43 за 1930 г.

От газеты «Xostuq arat» в данной подшивке имеются всего 24 номера: с 1 по 8, 20, 34, 42, 68, 43, $44,45,47 ; 60,61,62,64 ; 76,78,79$ и 80 за январь, март, апрель, май, июнь август, сентябрь и октябрь месяцы. Вовсе отсутствуют номера за февраль, июль, ноябрь и декабрь. Таким образом, от 48 годовых номеров почти половины нет. От газеты «گ̧ьn» в комплекте прошиты всего несколько номеров за 1932 г. Наиболее полные номера за февраль и декабрь.

В данном комплекте-подшивке обнаружен также всего один номер газеты «Leninnin oruu» («Путь Ленина») от 19 августа 1944 г. Газета представляла собой объединенный печатный орган партийных комитетов и Президиумов Малых хуралов 8 районов ТНР: Улуг-Хемского, Чаа-Хольского, Сут-Хольского, Барыын-Хемчикского, Бай-Тайгинского, Монгун-Тайгинского, Овюрского и Чоон-Хемчикского. Выпущена в типографии г. Чадаан. Газета напечатана на тувинском языке новотюркским латинизированным алфавитом. 


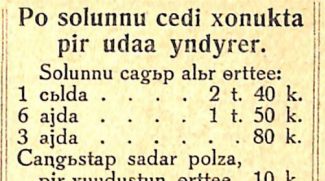

poştansn erengej xoraazs, kedee kozu unnarda postanbn salsurlarb polga Solun syyr cernin turar ceri: Kbzbl-xooraj, Revolustun sely, nam tep komitedi.

№ 12 (55)

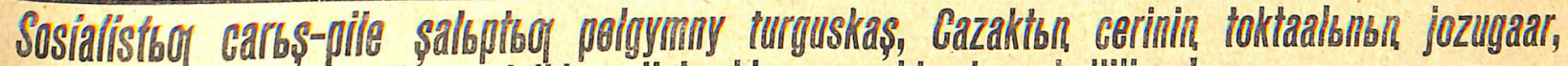 Tьва pizikke șilcip kirer coruktu tyrgededililiner!}

\section{Sosialistbo carbștbn kereezi.}

Ulustun yzyk piziin kozu-|bn "Șbn" teer solununga nnarnon ile sajzbradbr tugajbnda, a ratk or tep kizilerni $2 \%$ aа-xemnin kozuunu sosial- dan евеeș eвes songuur.

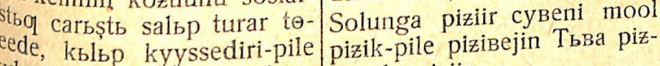
yleettinip taojdbnsp algan zblb polza:

1. Cazaktbn cerinin tokta1. Cazaktbn cerinin tokta-
gymnerinin arazbnga orul-
dulga kicceeli polgas $u k$
bn bn jozuzu-pile, $1931 \mathrm{cbl}$ maj ajnon 1-ge cedir surguuldun tyrymy paza pikozuun istinge kajb- ziirde caraș todargaj kbldbr

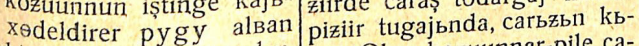
rekti caa pizik-pile corudar. lbr. Okse kozuunnar-pile ca2. Kozuun sumularda lik- rıș kblbrda "Şın" teer solntu surguuldarb polgas unga carlaar, cargan kereeaa piziktin pelgymneri, şko- lernin tengen xuussazbn 1931 nsh cugula azblbnsn xerksel cyBezin uk azblga saat olanbn ceringe 40 xardan udu kizilerni polgas paza pizik pelgymyn likpuntu rguuldun azblсьn jadbb

rattarbn $100 \%$ elzedip kirer.

3. ljuli ajda polur T.A.R. $\mathrm{cbl}$ polganbnon Ulustun or pajorbnon pettinde, po tkan 3 aj istinde, kozuun imularnon asstinde, kozuun xaarlarb nemeer каzььr суве pay pola, tyrgeni-pile solunga carp tsnnadbron tileer tur-pis. Kaa-xem kozuunu Xorlu.
Ulustun albanьnьn cerlerinin piziinin azblьn Тьва уzykke pyryny-pile cilcider tugajonda Cazaktbin cerinin 13 tugaar xuralbnbn toktaalib.

Ulustun azbl agbjь polgaş|rudup kyyssedirde, arat tym- Portta camdsk \$sdambk erttem polsassbralbnsn xer- ennin pottarb-pile cazak ca- alsan kblbrlar polgan polza, een ery telgeredirde ulustun gbrganın azbl-xereenge ki- caa pizikke occuldurar polcaa piziin arat xөjnyn araz- rișkeș, sosializmga tyrgen gaş xelemiccinin alвan azbbnga telgeredip corudar ncuor cugula.
polgaj.
Paza-taa arat tymenden $\mathrm{T}_{\mathrm{b}}$ polisassbraar coruktu la ergeleeri cok tur.

Msndьonsn teleezinde Paza-taa arat tymenden Tb- la ergeleeri cok tur. moon murnunda Cazaktbn вanьn caa pizinge eөrenir Portta tus cazaktsn cerincerinden toktaátkan xuussa- coruktu am po yjede uluq- den po tomaktangan idepkej non iștinde, cazak cagsrga la cidii-pile kicceep oraldaș- kicceel cok kizilerni kancaar

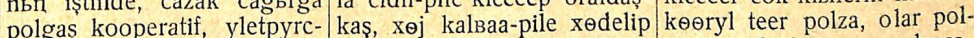
innin esilelderi paza pygy kedeenin kozuun sumularn- za tus ulustun caa polBassistinde caa piziktin pel- bralbnga șnb-pile tura cok albann likpuntu polgas sosializmga kirer oruazbl xereen tus ulustun caa gymneri polgaș, likpuntu polgaş sosializmga kirer orupizii-pile xedeldirip corudar teer pelgymnerni tus-tus tur- ktun moondaa polgaş cogum polza, ulustun polgaş arat guskaş, anıjak nazbnnıo coguur paaștaaşkınnı xylexөjge xemceo cok tegym uruo tarbqnь өөredip oral- евеs; ortta koncuq sagbzbn

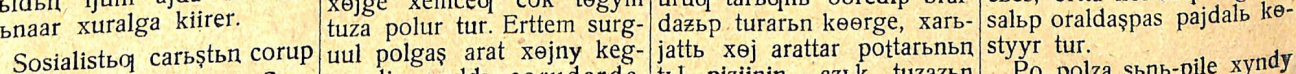

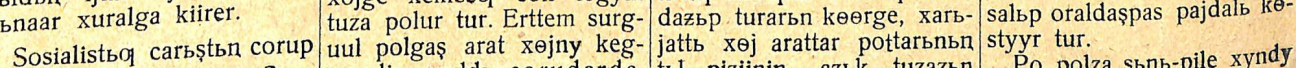
Sosialistıo carbştbn corup uul pos als corudarda, tbl piziinin azbk tuzazbn Po polza şsnb-pile xyndy

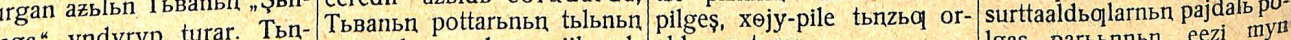
bnga" yndyryp turar. Ton- pizii-pile corudarga, ciik pel- aldazsp turar. lgas parbsnnon eezi my

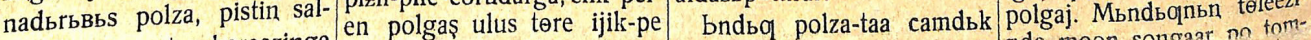
gan carbzbBbstbn kereezinge arat $x \Theta j n y n$ atbl agbjbnbn alsan cerlerinin iştinde kan- nde moon songaar nn toj

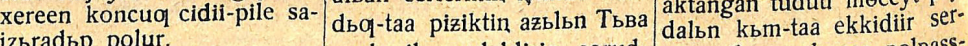
sradıp polur. Paza pygy alsannsn cerlerinin kandbo-taa azbl xer- arbnga araj \$sbdaalak tep po-
een tus tbldbn pizil-pile co- lur.

Фото 8. Первая полоса газеты «Şьп» от 30 марта 1931 г., хранящейся в газетном фонде Государственного архива Республики Тыва.

Photo 8. The front page of the Şbn newspaper (Newspaper collection SA RT).

По нашим данным, в фондах ГА РТ пока не обнаружены «Эрхэ чолоотэй бух Тува» («Освобожденная Тува»), выходившая в 1925-1930 гг. на монгольском языке, также ведомственные газеты «Кооперас оруу» («Путь кооперации») и «Тувинский горняк», освещавшие работу потребительских обществ республики и объем золотодобычи в ТНР.

Из монгольских периодических изданий в фондах ГА РТ хранятся «Монголын сонин бичиг» («Монгольские новости») за 1914-1916, 1918-1919 гг., «Монголын үнэн» («Монгольская правда») за 1930-1931 гг., «Монгол ардын үнэн» («Правда монгольского арата») за 1928-1931 гг., «Үнэн» («Правда») за 1928, 1931, 1934, 1936-1938, 1940 гг., «Залуучуудын үнэн» («Молодежная правда») за 1931-1932, 1936 гг., «Ардын эрх» («Народная власть») за 1925 г., «Ардын ундэсний эрх» («Монгольская власть») за 1933-1938 гг., «Нийслэл хүрээний үнэн бичиг» («Правда столицы») за 1915, 1917-1919 гг. Все они сконцентрированы в десяти комплект-подшивках. Имеется также одна подшивка бурятской газеты «Бурят-монголын үнэн» («Бурят-Монгольская правда») за 1929-1932 гг. Эти газеты до 1921 г. выписывались из Монголии и Бурятии отдельными чиновниками Тувы, а после создания ТНР специально для приобретения книг, журналов и газет в эти республики отправлялись члены ЦК ТНРП (Танова, 1979: 19).

Хранение и сохранность печатных изданий, в том числе периодических, имеют большое значение, ибо каждое из них является самостоятельным культурным явлением и конкретным информационным ресурсом, свидетельствующим об уровне развития общества. Поэтому можно только сожалеть о том, что в подшивках присутствуют столь значительные пробелы. 


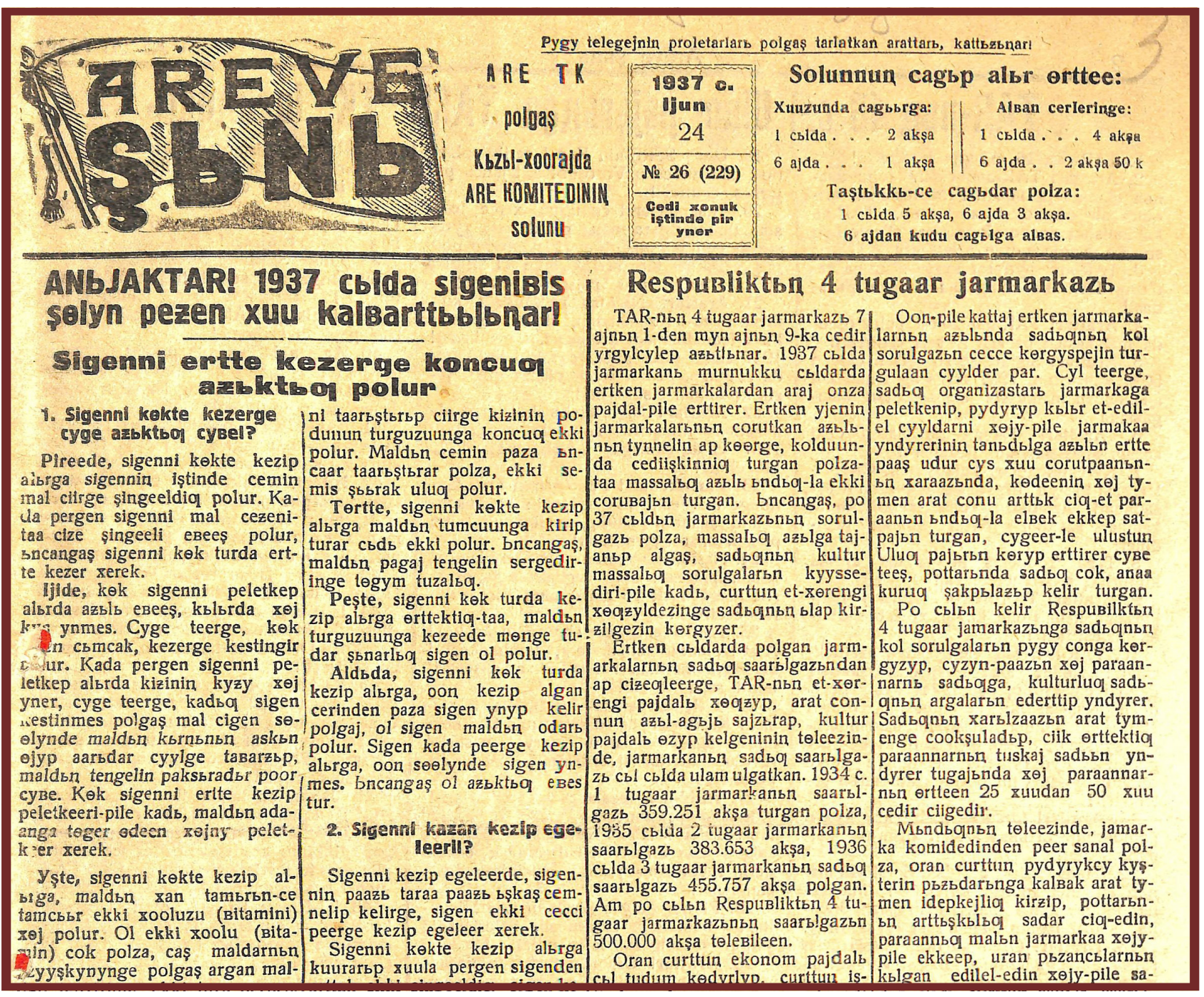

Фото 9. Первая полоса газеты «Areve şьпь» от 24 июня 1931 г., хранящейся в газетном фонде Государственного архива Республики Тыва.

Photo 9. The front page of the Areve şbnь newspaper (Newspaper collection SA RT).

\section{Содержание материалов в газетах ТНР}

Газеты «Красный пахарь», «Новый путь», «Вперед»

В этих газетах особое внимание отводилось освещению перемен, происходящих в Советском Союзе. Печатались материалы, например, о геологических открытиях на территории СССР, об индустриализации, о строительстве железной дороги или расширении Московского метрополитена. Например, в одном из декабрьских номеров газеты «Красный пахарь» за 1929 г. писали об открытии движения поездов на вновь выстроенной железнодорожной линии «Петропавловск-Акмолинск» ${ }^{1}$ Освещались также успехи советских пятилеток. Например, в газете «Вперед» писали: «...Советский союз занял первое место в мире по производству тракторов - в год выпускает 140 тысяч тракторов; по производству сельхозмашин, общему машиностроению и комбайнов. И Советский союз по уровню промышленной продукции вышел на второе место в мире после Америки, обогнав Францию, Англию и Германию...» ${ }^{2}$

Писателю М. Горькому посвящена статья «Подарок Алексею Максимовичу»: «...66-летию его дня рождения коллектив ударников рабочих, инженеров итехников Центрального Аэрогидродинамического института закончил постройку самолета. Самолет, носящий имя М. Горького, стал крупнейшим в мире

${ }^{1}$ Новая железная линия (1929) // Красный пахарь. 17 декабря.

${ }^{2}$ СССР на пороге 17-й годовщины (1934) // Вперед. 19 октября. 
самолетом. В нем оборудован ряд кабин, в которых будут находиться типография, электростанция, радиогромкоговорители и большая передвижная установка звукового кино» ${ }^{1}$ Далее сказано, что самолет будет совершать регулярные рейсы по заявкам колхозов, совхозов, заводов, новостроек и МТС и право на прием воздушного корабля будут иметь самые лучшие хозяйства.

В газете «Вперед» выходили статьи о планах расширения строительства г. Кызыла, о переходе государственных, хозяйственных и общественных организаций города на угольное топливо. Разъяснялось, что основным топливом города является дрова, для чего используется много строевого леса, что очень невыгодно и «...граничит с явной преступностью»². В статье приведены многочисленные факты об использовании для топлива кедрового леса, что способствует уничтожению ореха и уменьшению пушного зверя.

Печатались также сведения об очередном запуске электростанций в колхозах республикиз

Газета «Тувинская правда»

Анализ содержания газеты, хранящейся в ГА РТ, показывает, что в годы Великой Отечественной войны постоянными рубриками были «Иностранная хроника», «Обзор иностранных событий», «Обзор международных событий», «От Советского Информбюро», «Письма с фронта», «Партийная жизнь», «Советы врача», «Действующая армия» и некоторые другие. Например, крупным событием в жизни республики за 1942 г. стал запуск первого планера в стране. Об этом писали: « ... в присутствии членов правительства, членов ЦК ТНРП, дипломатических представителей СССР и МНР на Кызылском аэродроме производилось испытание планера, впервые построенного в ТНР. Пилотировал планер командир авиазвена т. Кидиспей ...» .

В постановлении Военного Совета Брянского фронта, опубликованном в номере за 7 марта 1943 г., говорилось о тувинской делегации из 12-ти человек во главе с секретарем ЦК ТНРП С. К. Тока, прибывшей на фронт. Делегация доставила 40 вагонов подарков для бойцов и командиров частей Брянского фронта. В честь дружбы и солидарности с дружественным тувинским народом, оказывающим всемерную помощь Красной Армии в разгроме немецко-фашистских захватчиков, Военный Совет фронта постановил, что зачисляет почетными бойцами в состав Н-ской Гвардейской стрелковой дивизии следующих представителей тувинского народа: секретаря ЦК ТНРП тов. Тока, министра внутренних дел ТНР тов. Товариштая, виднейшего скотовода ТНР тов. Кудажи и секретаря хошунного комитета ТНРП тов. Токтугу. Согласно данному постановлению, им были вручены гвардейские знаки

После вхождения ТНР в состав СССР в 1944 г. в республике из обращения была изъята тувинская акша - национальная валюта. В 14-м номере «Тувинской правда» от 20 декабря 1944 г. опубликована таблица для перерасчета тувинской валюты в советскую, соотношение которой составляло: 1 акша равна 3 рублям 50 копейкам.

Газета «క̧ьn»

В период введения новой тувинской письменности на страницах газеты «\$̧ьn» и ее предшественников «Тьва arattın şьnь» и «Ynen» печатались различные методические материалы, в частности, инструкция по изучению нового тувинского алфавита (1 января 1931 г.). Здесь же опубликованы лозунги к 10-летию ТНР и о борьбе с врагами СССР «Pygy telegejnin azblcsnnarb pottarınьn adazь polur S.S.R.E-ni kamgalap şьdaar!»

Основными рубриками газеты «Şьn» были «Даштыкы чурттарда» («В других странах»), «Нам ажылы» («Партийная работа»), «Чаа сөстер» («Новые слова»), «Кооперас булуңу» («Уголок кооперации»), «Ветеринар эмчиниң сүмелери» («Советы ветеринара»), «Бүдүрүлге булуну» («Производственный уголок»), «Хоорайда» («В городе»), «Тарылга медээзи» («Вести о посевных»), «Ада-чурттуң Улуг дайынының маадырлары» («Герои Великой отечественной войны») и др.

B рубрике «Carlal» («Объявления») выходили разные материалы. Например, в номере 11 от 6 февраля 1943 г. опубликовано объявление Комитета по делам искусств: «С 1 января 1943 года в городе Кызыле

${ }^{1}$ Подарок Алексею Максимовичу (1934) // Вперед. 20 апреля.

${ }^{2}$ O переходе государственных, хозяйственных и общественных организаций г. Кызыла на угольное топливо

(1935) // Вперед. 12 апреля.

${ }^{3}$ В колхозе «Пламя революции» пушена в ход электростанция (1936) // Вперед. 28 января.

${ }^{4}$ Взлет первого планера в ТНР (1942) // Тувинская правда. 8 апреля.

${ }^{5}$ Постановление Военного Совета Брянского фронта от 11 марта 1943 г. №1 (1943) // Тувинская правда. 8 апреля. 
в помещении Госкино открыта художественная мастерская. Мастерской производится прием заказов на всевозможные виды художественных работ от организаций, а также и от частных лиц: на портреты, плакаты, пано, и пейзажи...» Или объявление в номере от 9 июня 1943 г. дирекции кожевенного завода о том, что требуется кора ивы и ели в неограниченном количестве; цена за 1 килограмм привезенной коры - 8 копеек».

«Revane şьпь» («Ревсмольская правда»)

На страницах этой газеты освещались самые различные стороны общественной жизни ТНР: от вопросов государственного строительства до текстов новых песен. Кроме того, газета оперативно информировала о важных решениях партии, ревсомола, об актуальных задачах дня, о международном положении и т. д. В 1936 г. была переименована в «Areve şьпь». Главными ее рубриками были «Даштыкыда» («За рубежом), «Пионер булуңу» («Уголок пионера»), «Аревэ ажылы» («Дела ревсомола»), «Уруглар булуңу» («Детский уголок»), где публиковались сказки, стихотворения, песни и пр. Поскольку в ТНР работа по ликвидации неграмотности среди аратов шла почти непрерывно, здесь также периодически публиковались статьи методического характера. Например, в статье от 14 января 1937 г. «Pizikke, oon tyrymynge өөreniner» («Изучайте письменность и правила правописания») опубликован тувинский алфавит их 29 букв, из которых 8 выражают гласные звуки: а, ь, o, u, e, i, ө, у.

В 1944 г., после вхождения ТНР в состав СССР, газета стала называться «Тываның аныяктары» («Молодежь Тувы») и сегодня является одной из популярных периодических изданий республики (http:// anyiaktar.rtyva.ru/).

Газета «Хоstuб arat» («Свободный арат»)

Основными рубриками газеты были «Херээженнер булуңу» («Уголок для женщин»), «Советтиң информбюрозунуң дыңнадыгларындан» («Известия Советского информбюро»), «Даштыкы чурттарда» («За рубежом»), «Бистиң харыывыс» («Наши ответы») и т. д. В связи с переводом тувинской письменности с латинизированного алфавита на русский с 1941 г. в газете появились новые рубрики. Это «Чаа бижик булуңу» («Уголок новой письменности»), «Чаа бижик өөренирлерге» («Для изучающих новую письменность»), где материалы печатались на кирилице.

Во всех газетах времени ТНР часто публиковалась информация о ценах на товары и услуги, объявления о предоставлении различных услуг, деятельности властных структур и общественных организаций. Публиковались также «маленькие фельетоны», критикующие недостатки людей, плохую работу или поступки руководителей, председателей арбанов, членов товариществ и других общественных организаций. Почти в каждой газете мы можем видеть некрологи, в первую очередь, советских руководителей и известных личностей. Например, сообщение о смерти К. Э. Циолковского (1 октября 1935 г.), Г. В. Чичерина - народного комиссара по иностранным делам (24 июля 1936 г.), С. М. Кирова - секретаря Ленинградского губкома ВКП(б) (5 декабря 1934 г.), материал об отпевании скончавшегося святейшего патриарха Московского и всея Руси Сергия (24 мая 1944 г.) и т. д.

Материалы имеющихся газет показывают самые разные стороны жизни тувинского общества, которые мы показали только штрихами, и представляют огромную источниковую ценность для исследователей истории Тувы.

\section{Использование и сохранность газетного фонда}

Ежегодно выдача газетных подшивок из архивохранилища возрастает. Исследователям газеты выдаются в читальный зал архива. Статистика запросов показывает следующую картину.

Если взять новый XXI в., то с 2001 по 2017 гг. здесь занимались 8500 человек (Бондаренко, 2018: 93). Самое больше их число пришлось на 2013 г., на предъюбилейный период - к 2014 г., когда республика готовилась к 100-летиюустановления отношений Тувы с Российской империей и 100-летию образования г. Кызыла, столицы республики. Для раскрытия своих тем, интерес к которым значительно возрос в тот период, многие исследователи использовали газетные материалы. Например, при написании второго тома коллективной монографии «История Тувы» (охватывающей хронологически период с российского протектората над Тувой, времени Тувинской Народной Республикой, до ее вхождения в состав СССР), были привлечены материалы газеты «Новый путь», «Вперед» и т. д. (История Тувы, 2007: 190, 362, 414, 426) и т. д. Свежие публикации способствовали новому освещению процессов перевода аратских хозяйств на оседлость, развития советско-тувинских отношений во время Великой Отечественной войны и т. д. Из отдельных трудов можно отметить монографию Н. П. Москаленко 
«Этнополитическая история Тувы в XX в.». Автор использовала публикации из «Тувинской правды» и других газет (Москаленко, 2004: 194, 183, 211, 212).

Сами архивисты использовали подшивки-комплекты газетного фонда при подготовке ряда работ. Например, в сборник, посвященный развитию физической культуры и спорта в ТНР, включены 39 публикаций из газет «Вперед», «Шын», «Аревэ шыны» и «Тувинская правда» (Сборник архивных документов, .... , 2013). Они также регулярно используют газеты при подготовке тематических выставок, приуроченных различным юбилейным датам.

К газетному фонду архива часто обращаются представители республиканских средств массовой информации. Номера предыдущих лет они используют, например, для подготовки в газетах специальных исторических колонок типа «30, 40, 50 или 70 лет назад».

Помимо использования документов - как самим архивом, так и его пользователями, другой важнейшей - уже внутренней задачей архива - является проблема обеспечения сохранности документов. Данный вопрос для ГА РТ имеет особую остроту. Усилия сотрудников направлены на формирование комплектов-подшивок, для чего газеты сдаются в республиканскую типографию на переплет. Подшивки хранятся в архивохранилище № 3, размещены на архивных стеллажах в горизонтальном положении. Со временем их вполне можно классифицировать в архивную коллекцию.

В ходе обследования газетного фонда выявляются случаи ухудшения физического состояния газет. У многих номеров имеются механические повреждения: закручивание углов, следы перегибов, мятые и рваные листы. Часть текстов стала трудночитаемой. Данные факты обусловлены, в первую очередь, постоянным использованием, качеством бумаги и условиями хранения.

В настоящее время в ГА РТ идет разработка программы по оцифровке газет, устанавливаются контакты с Региональным центром консервации документов, действующей при Научной библиотеке Томского государственного университета. В самом архиве технологические возможности ограничены.

\section{Заключение}

Газетный фонд Государственного архива Республики Тыва, несмотря на его пробелы, является крупным собранием. В историко-культурологическом, информационно-документном аспекте особо ценны газеты, выходившие в Тувинской Народной Республике. Они являются письменными, книжными и культурными памятниками, составляющими объемный информационный ресурс для изучения истории региона. Если газеты советского времени можно находить в других архивах, в том числе других регионов страны, то восполнить состав газет периода ТНР чрезвычайно сложно.

В планах ГА РТ значится ряд проектов, например, создание каталога газет (печатного и электронного), хранящихся не только в архиве, но и в других архивохранилищах республики, по возможности поиск отсутствующих газет.

С точки зрения исследовательского подхода газетный фонд архива нуждается в подробном анализе по разным аспектам. Углубленно можно изучить отдельные газеты или запросы пользователей по тематическим направлениям, создавать базы данных, что позволят восстановить многие события и факты минувших лет, еще не введенные в научный оборот.

\section{СПИСОК ЛИТЕРАТУРЫ}

Бондаренко, Т. А. (2018) Использование документов Государственного архива Республики Тыва (XXI в.) // Роль и значение архивов и архивных документов в сохранении исторической памяти народа. Материалы региональной научно-практической конференции, посвященной 100-летию государственной службы России. 26 апр. 2018 г., Республика Тыва, г. Кызыл / отв. ред. В. Б. Мунге. Кызыл : Типография КЦО «Аныяк». 124 с. С. 92-94.

Есин, И. Б. (1981) Русская газета и газетное дело в России. Задачи и теоретико-методические принципы изучения. М. : Изд-во Моск. ун-та. 132 с.

Грибановская, А. М. (2017) Ежедневная газета в России. Организация издания, финансовое положение, правовой статус (1860-е - начало 1880-х гг.) : автореф. дисс.... канд. ист. наук. М. 24 с.

История Тувы (2007) / под общ. ред. В. А. Ламина. Новосибирск : Наука. Т. II. 430 с.

Кан, В. С. (2010а) Из истории газеты «Сылдысчыгаш» (1945-1959 гг.) К 65-летию газеты [Электронный ресурс] // Новые исследования Тувы. № 1. С. 173-187. URL: https://nit.tuva.asia/nit/article/view/571 (дата обращения: 12.01.2020). 
Кан, В. С. (2010b) Мероприятия по усилению роли периодической печати в тувинском обществе (первая половина 1930-х гг.) // Ученые записки. Вып. ХХІІ. Кызыл : ОАО «Тываполиграф». 504 с. С. 145-158.

Кан, В. С. (2011) Газетная периодика Тувы: особенности становления и развития. LAMBERT Academic Publishing. 128 c.

Косова, Е. С., Данилова, Е. А. (2018) Газетный фонд Научной библиотеки Томского государственного университета (сохранность, оцифровывание, использование) // Одиннадцатые Макушинские чтения. Материалы научной конференции / отв. ред. С. Н. Лютов. Новосибирск : ГПНТБ СО РАН. 443 с. С. 151-159.

Ледкова, Л. П. (2016) Периодическая печать в сельскохозяйственном просвещении Забайкалья в 1912-1926 гг. По материалам Государственного архива Забайкальского края // Вестник архивиста. № 1. С. 173-187.

Маадыр, М. С. (2018) Журналы Тувинской Народной Республики в современных архивохранилищах // Роль и значение архивов и архивных документов в сохранении исторической памяти народа. Материалы региональной научно-практической конференции, посвященной 100-летию государственной службы России. 26 апр. 2018 г., Республика Тыва, г. Кызыл / отв. ред. Б. В. Мунге. Кызыл : Типография КЦО «Аныяк». 124 с. С. 43-47.

Москаленко, Н. П. (2004) Этнополитическая история Тувы в XXI веке. М. : Наука. 223 с.

Потемкина, М. Н., Макарова, Н. Н., Любецкий, А. Е. (2018) Материалы нелегальной тюремной прессы как источник по истории большевистской оппозиции конца 1920 - начала 1930-х гг. // Вестник архивиста. № 3. С. $844-855$. DOI: https:/www.doi.org/10.28995/2073-0101-2018-3-844-855

Сборник архивных документов, статей из газет по развитию физической культуры и спорта в ТНР (2013) / сост. А. М. Дугар-Сюрюн и др. Кызыл : КЦО «Аныяк». 107 с.

Сизов, С. Г. (2018) Омские газеты как источник повседневной жизни Белой столицы России (июнь 1918 - ноябрь 1919 г.) // Одиннадцатые Макушинские чтения. Материалы научной конференции / отв. ред. С. Н. Лютов. Новосибирск : ГПНТБ СО РАН. 443 с. С. 364-372.

Танова Е. Т. (1979) Периодическая печать Тувы (1921-1944 гг.). Кызыл : Тувкнигоиздат. 112 с.

Шактар-оол, Ч. Б. (2018) Кинодокументы в фондах Государственного архива Республики Тыва: хранение и использование // Роль и значение архивов и архивных документов в сохранении исторической памяти народа. Материалы региональной научно-практической конференции, посвященной 100-летию государственной службы России. 26 апр. 2018 г., Республика Тыва, г. Кызыл / отв. ред. В. Б. Мунге. Кызыл : Типография КЦО «Аныяк». 124 с. C. 89-91.

Шереметьева, Д. Л. (2011) Газеты Сибири в период «демократической контрреволюции» : автореф. дисс. ... канд. ист. наук. Новосибирск. 24 с.

Дата поступления: 02.03.2020 г.

\section{REFERENCES}

Bondarenko, T. A. (2018) Ispol'zovanie dokumentov Gosudarstvennogo arkhiva Respubliki Tyva (XXI v.) [Using documents from the State archive of the Republic of Tuva in the 21 st century]. In: Rol' $i$ znachenie arhhivov $b$ arkhivnykh dokumentov $v$ istoricheskoi pamiati naroda. [Role and importance of archives and archival documents in historical memory of a people]. Proceedings of the regional conference devoted to the 100th anniversary of the Archival Service of Russia. Republic of Tuva, Kyzyl, April 26, 2018. Ed. by B. V. Munge. Kyzyl, Gosarhiv RT, TyvGU. 124 p. Pp. 92-94. (In Russ.).

Esin, I. B. (1981) Russkaia gazeta i gazetnoe delo v Rossii. Zadachi i teoretiko-metodicheskie printsipy izucheniia [Russian newspapers and newspaper business in Russia. Challenges and theoretical and methodological principles of study]. Moscow, Izd-vo Mosk. un-ta. 132 p. (In Russ.).

Gribanovskaia, A. M. (2017) Ezhednevnaia gazeta v Rossii. Organizatsiia izdaniia, finansovoe polozhenie, pravovoi status (1860-e - nachalo 1880-kh gg.) [Daily newspapers in Russia. Structure, financial situation and legal status from 1860s to early 1880s)] : Thesis of Diss.... Candidate of History. Moscow. 24 p. (In Russ.).

Istoriia Tuvy [The History Of Tuva] (2007): in 3 vols. / ed. by V. A. Lamin. Novosibirsk, Nauka. Vol. 2. 430 p. (In Russ.).

Kan, V. S. (2010a) Iz istorii gazety «Syldyschygash» (1945-1959 gg.) K 65-letiiu gazety [A history of the Syldyschygash newspaper (1945-1959) to the 65th anniversary]. The New Research of Tuva, no. 1, pp. 173-187 [online] Available at: https://nit.tuva.asia/nit/article/view/571 (access date: 12.01.2020). (In Russ.).

Kan, V. S. (2010b) Meropriiatiia po usileniiu roli periodicheskoi pechati v tuvinskom obshchestve (pervaia polovina 1930-kh gg.) [Measures to strengthen the role of the periodical press in Tuvan society in the first half of the 1930s]. Uchenye zapiski. Vol. XXII. Kyzyl, OAO «Tyvapoligraf». 504 p. Pp. 145-158. (In Russ.).

Kan, V. S. (2011) Gazetnaia periodika Tuvy: osobennosti stanovleniia i razvitiia [Newspapers in Tuva: rise and developent]. LAMBERT Academic Publishing. 128 p. (In Russ.). 
Kosova, E. S. and Danilova, E. A. (2018) Gazetnyi fond Nauchnoi biblioteki Tomskogo gosudarstvennogo universiteta (sokhrannost', otsifrovyvanie, ispol'zovanie) [Newspaper collections at the Research library of Tomsk State University: Preservation, digitization and use)]. In: Odinnadtsatye Makushinskie chteniia [11th Makushin readings]. Proceedings of a research conference / ed. by S. N. Liutov. Novosibirsk, GPNTB SO RAN. 443 p. Pp. 151-159. (In Russ.).

Ledkova, L. P. (2016) Periodicheskaia pechat' v sel'skokhoziaistvennom prosveshchenii Zabaikal'ia v 1912-1926 gg. Po materialam Gosudarstvennogo arkhiva Zabaikal'skogo kraia [Periodical press in the agricultural education of Transbaikalia in 1912-1926: Based on the materials from the State Archives of the Trans-Baikal Territory]. Vestnik arkhivista, no. 1, pp. 173-187. (In Russ.).

Maadyr, M. S. (2018) Zhurnaly Tuvinskoi Narodnoi Respubliki v sovremennykh arkhivokhranilishchakh [Journals of the Tuvan People's Republic in modern archives]. In: Rol' $i$ znachenie arhhivov $b$ arkhivnykh dokumentov $v$ istoricheskoi pamiati naroda. [Role and importance of archives and archival documents in historical memory of a people]. Proceedings of the regional research conference devoted to the 100th anniversary of the Archive Service of Russia. Republic of Tuva, Kyzyl, April 26, 2018. Ed. by B. V. Munge. Kyzyl, Gosarhiv RT, TyvGU. 124 p. Pp. 43-47. (In Russ.).

Moskalenko, N. P. (2004) Etnopoliticheskaia istoriia Tuvy v XX veke [Ethnopolitical history of Tuva in the 20th century]. Moscow, Nauka. 222 p. (In Russ.).

Potemkina, M. N., Makarova, N. N. фтв Liubetskii, A. E. (2018) Materialy nelegal'noi tiuremnoi pressy kak istochnik po istorii bol'shevistskoi oppozitsii kontsa 1920 - nachala 1930-x gg. [Illegal prison press materials as a source on the history of the Bolshevik Opposition of late 1920s - early 1930s]. Herald of an archivist, no. 3, pp. 844-855. (In Russ.). DOI: https:// www.doi.org/10.28995/2073-0101-2018-3-844-855

Sbornik arkhivnykh dokumentov, statei iz gazet po razvitiiu fizicheskoi kul'tury i sporta $v$ TNR [A collection of archival documents and newspaper articles on the development of physical culture and sports in the PRT] (2013) / comp. by A. M. DugarSurun et al. Kyzyl, KTsO «Anyiak». 107 p. (In Russ.).

Sizov, S. G. (2018) Omskie gazety kak istochnik povsednevnoi zhizni Beloi stolitsy Rossii (iiun' 1918 - noiabr' 1919 g.) [Omsk newspapers as a source for studying everyday life in the White capital of Russia, June 1918 - November 1919]. In: Odinnadtsatye Makushinskie chteniia [1 $1^{\text {th }}$ Makushin readings]. Proceedings of a research conference / ed. by S. N. Liutov. Novosibirsk, GPNTB SO RAN. 443 p. Pp. 364-372. (In Russ.).

Tanova E. T. (1979) Periodicheskaia pechat' Tuvy (1921-1944 gg.) [Periodical press in Tuva, 1921-1944]. Kyzyl, Tuvan book publ. 112 p. (In Russ.).

Shaktar-ool, Ch. B. (2018) Kinodokumenty v fondakh Gosudarstvennogo arkhiva Respubliki Tyva: khranenie i ispol'zovanie [Film documents in the collections of the State Archives of the Republic of Tuva: storage and use]. In: Rol' $i$ znachenie arhhivov $b$ arkhivnykh dokumentov $v$ istoricheskoi pamiati naroda. [Role and importance of archives and archival documents in historical memory of a people]. Proceedings of the regional conference devoted to the 100th anniversary of the Archive Service of Russia. Republic of Tuva, Kyzyl, April 26, 2018. Ed. by B. V. Munge. Kyzyl, Gosarhiv RT, TyvGU. 124 p. Pp. 89-91. (In Russ.).

Sheremet'eva, D. L. (2011) Gazety Sibiri v period «demokraticheskoi kontrrevoliutsii» [Newspapers of Siberia in the period of "Democratic counterrevolution"]: Thesis of Diss. ... Candidate of History. Novosibirsk. 24 p. (In Russ.).

Submission date: 02.03.2020. 